\title{
Retraction Note to: Long non-coding RNA SATB2-AS1 inhibits microRNA-155-3p to suppress breast cancer cell growth by promoting breast cancer metastasis suppressor 1-like
}

\author{
Shaogiang Cheng ${ }^{1 \dagger}$, Bingshu Xia ${ }^{1 \dagger}$, Hongbin $\mathrm{Li}^{2}$, Yuying $\mathrm{Li}^{2}$, Xinxin $\mathrm{Lv}^{2}$, Yue Zhang ${ }^{2^{*}}$ and Yuanxi Huang ${ }^{1 *}$ (D)
}

\section{Retraction to: Cancer Cell Int (2020) 20:321 https://doi.org/10.1186/s12935-020-01411-8}

The Editors-in-Chief have retracted this article [1]. Concerns were raised with a number of figures, specifically:

- Fig. 3d blank cell culture for MDA-MB-231 and MCF-7 appear identical to Fig. 4d blank cell culture for MDA-MB-231 and MCF-7 respectively.

- Fig. $3 \mathrm{~d}$ charts appear to be identical to all Fig. $4 \mathrm{~d}$ charts.

- Fig. 3f blank cell cultures appear to be the same as Fig. $4 \mathrm{f}$ blank cell cultures.

- Fig. 3g blank cell cultures appear to be the same as Fig. $4 \mathrm{~g}$ blank cell cultures.

- Fig. 3i blank tissue samples appear to be the same as Fig. 4i blank tissue samples.

Additionally, the Editors-in-Chief found that blank control values are missing in the raw data for Fig. $4 \mathrm{a}$ and that the variation between miRNA mimic and miRNA inhibitor appears to be unrealistically small. The Editorsin-Chief have therefore concluded that the data reported in this article are unreliable.

The authors agree with the retraction but disagree with the wording of the retraction notice.

Published online: 14 February 2021

\section{Reference}

1. Cheng S, Xia B, Li H, Li Y, LV X, Zhang Y, Huang Y. Long non-coding RNA SATB2-AS1 inhibits microRNA-155-3p to suppress breast cancer cell growth by promoting breast cancer metastasis suppressor 1-like. Cancer Cell Int. 2020;20:321. https://doi.org/10.1186/s12935-020-01411-8.

\section{Publisher's Note}

Springer Nature remains neutral with regard to jurisdictional claims in published maps and institutional affiliations.

(c) The Author(s) 2021. This article is licensed under a Creative Commons Attribution 4.0 International License, which permits use, sharing, adaptation, distribution and reproduction in any medium or format, as long as you give appropriate credit to the original author(s) and the source, provide a link to the Creative Commons licence, and indicate if changes were made. The images or other third party material in this article are included in the article's Creative Commons licence, unless indicated otherwise in a credit line to the material. If material is not included in the article's Creative Commons licence and your intended use is not permitted by statutory regulation or exceeds the permitted use, you will need to obtain permission directly from the copyright holder. To view a copy of this licence, visit http://creativecommons.org/licenses/by/4.0/. The Creative Commons Public Domain Dedication waiver (http://creativecommons.org/publicdomain/zero/1.0/) applies to the data made available in this article, unless otherwise stated in a credit line to the data. 